\title{
A Model of Emission Trading for Minimizing the Cost of Air Pollution Control from Belgian Power Plants
}

\author{
Walter Hecq and Bruno Kestemont \\ Unité d'Ecologie, Centre d'Economie Politique, Université Libre de Bruxelles, \\ Belgium
}

Received 16 March 1990

In Belgium recent national and community legislation regulates emission levels of "acid pollutants" $\left(\mathrm{SO}_{2}, \mathrm{NO}_{x}\right)$ and apply to large combustion facilities whose pollutants are transported over large distances.

Complying with these legislations requires costly emission control equipment. In order to minimize the costs of clean-up operations, this paper analyses the potentialities of an emission trading programme by means of a linear programming model. Six retrofit power plants have been chosen to test the model.

As the results suggest, substantial credits are obtained for either $\mathrm{SO}_{2}$ or $\mathrm{NO}_{x}$ emissions reduction.

Keywords: emission trading, linear programming model, power plants, $\mathrm{SO}_{2}$, $\mathrm{NO}_{x}$, emission control, Belgium.

\section{Introduction}

In response to the damage caused in recent years by "acid" pollutants $\left(\mathrm{SO}_{2}\right.$ and $\left.\mathrm{NO}_{x}\right)$, the European countries-Belgium included-and the EEC have promulgated regulations requiring large-scale air-pollution control. Amongst the sources of pollution affected by these regulations, there are the thermal power plants, whose smokestacks scatter pollutants over wide areas. In order to comply with emission reduction standards (the maximum concentrations in the flue gas), these power plants will have to install costly control devices. In view of the high cost and its effect on the cost price per $\mathrm{kWh}$, ways must be sought to minimize the cost of specific cleaning-up operations. This was the context in which the idea of emission trading within groups of pollution sources was born.

The aim is to establish suitable emission levels for each source of pollution in such a way that:

1. There is an overall emission level identical to the one obtained through the application of the uniform legal emission standards, and that this overall level is not exceeded.

2. The emissions control costs incumbent upon the group are kept to a minimum. 
This type of strategy $†$ makes it possible to obtain a credit (Raufer et al., 1986) which reflects the difference between costs accrued from compliance with "uniform" legal emission standards on the one hand, and from the optimum emission trading formula on the other. The use of emission trading, and specially the "bubble" policy, has been approved by USEPA (Borowski and Ellis, 1987) and authorities from some other countries (e.g. Japan, Denmark, F.R.G.) (Rentz, 1986).

This paper aims to demonstrate the potentialities of an emission trading programme involving a group of traditional thermal power stations situated in Belgium.

\section{Method}

The method breaks down into five steps:

1. The evaluation of the emissions $\left(e_{n \mathrm{~L}}\right)$ corresponding to the application in each of the power plants of the maximum legally permissible limits so as to establish the overall residual emission targets not to be exceeded $\left(E_{T L}\right)$.

2. The formalization of the emissions reduction cost functions $\left(c_{n}\right)$.

3. The calculation of the cost of reducing emissions in compliance with legal emission standards $\left(c_{n \mathrm{~L}}\right.$ and $\left.C_{T \mathrm{~L}}\right)$.

4. Application of a linear programming model in order to minimize emissions reduction costs $\left(\mathrm{Min} C_{T}\right.$ ).

5. The calculation of the credit obtained through emission trading $\left(C_{T \mathrm{~L}}-C_{T \min }\right)$.

\subsection{FIRST STEP}

Sulphur dioxide $\left(\mathrm{SO}_{2}\right)$ and nitrogen oxides $\left(\mathrm{NO}_{x}\right)$ emissions are calculated, as are the emission reduction levels corresponding to the application of the legal emission standards:

$$
\begin{aligned}
E_{T \mathrm{~L}} & =\sum_{n} e_{n \mathrm{~L}} \\
E_{T 1} & =\sum_{n} e_{n 1} \\
\text { where } D_{T \mathrm{~L}} & =\sum_{n} d_{n \mathrm{~L}}=E_{T 1}-\mathrm{E}_{\mathrm{TL}}
\end{aligned}
$$

where: $E_{T L}=$ the total annual "legal" emissions of all the power plants selected for inclusion in the programme; $e_{n \mathrm{~L}}=$ the annual emissions from each power plant $n$ complying with the new legal emission standards. $E_{r 1}=$ current total annual emissions with no emission abatement technology; $e_{n 1}=$ the annual emissions from each power plant $n$ with no new pollution abatement technology; $d_{n \mathrm{~L}}=$ the cutback in emissions (tonnes/year) necessary to comply with the new legal emission standards; $D_{T \mathrm{~L}}=$ the minimum total annual emission abatement limit to be met.

\subsection{SECOND STEP}

A number of emissions abatement options $i$ are suggested for each power plant $n$. The cost functions $\left(c_{m}=f_{n}\left(d_{n}\right)\right)$, which include a number of fixed and variable costs, are established on the basis of a linear model.

Because of the linearization assumption, these cost functions are equal to the sum of 
a number of fixed $\left(C F_{n}\right)$ and variable $\left(C V_{n i}\right)$ costs according to the cut-back in emissions achieved. At least when the technology permits, the taking into consideration of the variable cost allows the part-use of this technology. This means that it is possible to cover intermediate reduction levels $\left(d_{n}\right)$, i.e. levels below those corresponding to the full use of the technologies $\left(d_{n \text { max }}\right)$.

The introduction of the concept of a choice-or a lack of choice-of emissions abatement technology is once again advisable. To this end, an on/off variable $\left(K_{n}\right)$ with 0 and 1 as its only values is added to the cost functions $\left(c_{n i}\right)$ as appropriate. With $C V M_{n i}$ (average variable cost), these can be finally written as:

$$
\begin{gathered}
c_{n i}=C F_{n i} \times K_{n t}+C V M_{n i} \times d_{n i} \\
\text { with } 0 \leqslant d_{n i} \leqslant d_{n \max } \times K_{n t}
\end{gathered}
$$

where $d_{n \max }$ : the maximum cutback in emissions for power plant $n$ using technology $i$. Thus, if: $K_{n i}=0, d_{n i}=0$ and $c_{n t}=0$ and if: $K_{n i}=1, d_{n i}$ ranges from 0 to $d_{n \max }$.

In this model, the base case emissions of a power plant $n$ corresponds to emissions abatement cost $c_{n 1}=0$ ( $i=1$ is technological option zero). In this case, the emissions abatement level attained equals $d_{n 1}=0$.

For cost $c_{n 2}$, the use of technology $(i=2)$ enables a first range of reduction level achieved $\left(d_{n 2}\right)$, with $0 \leqslant d_{n 2} \leqslant d_{n 2 \max }\left(d_{n 2 \max }=\right.$ the maximum cut-back in emissions obtained from the use of technology 2). A second range of reduction level $\left(0 \leqslant d_{n 3} \leqslant d_{n 3 \max }\right)$ can be dealt with by using a third technology $(i=3)$ for cost $c_{n 3}$, and so on.

Thus, the use of numerical data or graphical representation relating to cost functions $c_{n i}$ makes it possible to ascertain the emissions abatement cost for each level of emissions and also the emissions reduction level $\left(d_{n \mathrm{~L}}\right)$ corresponding to a compliance with the legal standard $\left(N_{\mathrm{L}}\right)$.

\subsection{THIRD STEP}

When a power plant $n$ complies with the legal standard and, in consequence, with emissions reduction level $d_{T \mathrm{~L}}$, the annual emissions abatement cost $\left(c_{n \mathrm{~L}}\right)$ is estimated on the basis of the cost functions. The result is: $c_{n \mathrm{~L}}=f_{n}\left(d_{n \mathrm{~L}}\right)$ together with the total annual pollution abatement cost $\left(C_{T \mathrm{~L}}\right)$ for the power plants:

$$
C_{T \mathrm{~L}}=\sum_{n} c_{n \mathrm{~L}}=\sum_{n} f_{n}\left(d_{n \mathrm{~L}}\right)
$$

\subsection{FOURTH STEP}

The problem amounts to selecting emission abatement options and levels for each power plant $n$ so that:

(a) The total control cost remains as low as possible.

$$
\min \sum_{n} c_{n}
$$

(b) The total annual emissions from the power plants are either below, or equal to, a maximum value $\left(E_{T L}\right)$ 


$$
\sum_{n} e_{n} \leqslant E_{T \mathrm{~L}}
$$

This second condition implies that the cutback in the emissions from the power plants is either above, or equal to, the overall value $\left(D_{T \mathrm{~L}}\right)$

$$
\sum_{n} d_{n} \geqslant D_{T \mathrm{~L}}
$$

where: $e_{n}=$ the emissions from power plant $n$ once they have been decreased; $E_{T L}=$ the maximum legally authorized emissions for all the power plants selected for inclusion in the emission trading programme; $c_{n}=$ the cost of reducing emissions from power plant $n$ to level $d_{n} ; d_{n}=e_{n 1}-e_{n}=$ cutback in emission from power plant $n ; e_{n 1}=$ current emissions from power plant $n$ (in the absence of any emissions abatement technology); $D_{T \mathrm{~L}}=$ the minimum level of emissions reduction to reach $E_{T \mathrm{~L}}$.

The minimization of cost function $\sum_{n} c_{n}$ means that a choice is made between the emissions abatement options characterized by the particular functions $c_{n i}\left(d_{n}\right)$.

An extra constraint must be introduced so that this choice between emission reduction technologies can be effected mathematically. So, in this model, we make use of the variable introduced earlier, i.e. $K_{n i}$, an on/off variable whose values are either 0 or 1 .

This constraint is expressed by:

$$
\sum_{i} K_{n i} \leqslant 1(i \neq 1)
$$

This constraint enables the cost of reducing power plants emission to be redetermined by the total of the fixed $\left(C F_{n i}\right)$ and variable $\left(C V_{n i}\right)$ costs for each technology (one cost corresponds to each total different from 0 ):

$$
C_{n}=\sum_{l} c_{n l}=\sum_{l}\left(C F_{n t} \times K_{n t}+C V M_{n t} \times d_{n l}\right)
$$

with $d_{n}=0$ and $c_{n}=0$ if $K_{m}=0$.

In order to extend the notion of the choice of a single technology per power plant to the whole group, it is sufficient to pursue the same line of iterations as above for each separate power plant and to introduce the relevant constraints. The total cost of reducing emissions is then expressed by:

$$
C_{T}=\sum_{n} C_{n}=\sum_{n i} c_{n i}
$$

If the constraints are taken into consideration that authorize the use of only one technology per power plant, the final equations (1) and (3) can be rewritten as:

$$
\min \sum_{n i} c_{m}=C_{T \min }
$$




$$
\begin{gathered}
\qquad \sum_{n i} d_{n t} \geqslant D_{T \mathrm{~L}} \\
\text { one technology } i \text { per power plant } n: \sum_{n i} K_{n t} \leqslant 1\left(K_{n t}=0 \text { or } 1\right)(i \neq 1)
\end{gathered}
$$

\subsection{FIFTH STEP}

The credit obtained is: credit $=C_{T L}-C_{T \min }$; with $C_{T \mathrm{~L}}$ being the total cost of reducing emission in the absence of emission trading (legal emission standards); and $C_{T \text { min }}$ being the total least cost of solution emission reduction with the employment of emission trading. This approach is applied to the reduction of both $\mathrm{SO}_{2}$ and $\mathrm{NO}_{x}$ emissions.

\section{Results}

\subsection{THE POWER PLANTS STUDIED}

No new power plants are scheduled for construction in Belgium for a number of years. Taking into consideration the ease with which data can be obtained on existing plants, we selected to include in the analysis five listed in the 1985/1989 coal conversion plan and a sixth which had been renovated after a breakdown (Hecq and Kestemont, 1988).

The characteristics specific to each of these six coal-fired plants are listed in Table 1.

\begin{tabular}{|c|c|c|c|c|c|c|}
\hline Plants & A & B & $\mathrm{C}$ & D & $\mathrm{E}$ & $\mathbf{F}$ \\
\hline Capacity $\left(\mathrm{MW}_{\mathrm{th}}\right)$ & 575 & 350 & 520 & 575 & 600 & 370 \\
\hline \multicolumn{7}{|l|}{ Coal } \\
\hline $\begin{array}{l}\text { Low heating value } \\
(\mathrm{MJ} / \mathrm{kg})\end{array}$ & $24 \cdot 2$ & $26 \cdot 8$ & $23 \cdot 5$ & $24 \cdot 4$ & $24 \cdot 5$ & $24 \cdot 5$ \\
\hline $\begin{array}{l}\text { Sulphur content } \\
\text { (\%weight) }\end{array}$ & 0.86 & 0.68 & 0.60 & 0.81 & 0.80 & 0.60 \\
\hline \multicolumn{7}{|l|}{ Coke-oven gas } \\
\hline & Not used & $18 \cdot 0$ & Not used & Not used & Not used & $18 \cdot 7$ \\
\hline Sulphur content $\left(\mathrm{g} / \mathrm{Nm}^{3}\right)$ & - & $4 \cdot 1$ & $\ldots$ & - & - & $7 \cdot 0$ \\
\hline \multicolumn{7}{|l|}{ Blast furnace gas } \\
\hline $\begin{array}{l}\text { Low heating value } \\
\left(\mathrm{MJ} / \mathrm{Nm}^{3}\right)\end{array}$ & Not used & Not used & Not used & Not used & 3 & Not used \\
\hline Nitrogen content (\%vol.) & - & - & - & - & 58 & - \\
\hline Plant operating (h/year) & 5735 & 6993 & 4704 & 5363 & 6194 & 5010 \\
\hline $\begin{array}{l}\text { Adaptability of pollution } \\
\text { control devices }\end{array}$ & Difficult & Easy & Easy & Difficult & Difficult & Easy \\
\hline \multicolumn{7}{|l|}{ Initial $\mathrm{SO}_{2}$ emissions } \\
\hline$\left(\mathrm{mg} \mathrm{SO}_{2} / \mathrm{Nm}^{3}\right) \dagger$ & 1590 & $\begin{array}{l}4419 \cdot 8 \\
1350\end{array}$ & $\begin{array}{l}3388 \cdot 8 \\
1130\end{array}$ & $\begin{array}{l}0305 \cdot / \\
1490\end{array}$ & $\begin{array}{l}5801 \cdot 1 \\
1225\end{array}$ & $\begin{array}{l}3181^{\cdot} 4 \\
1340\end{array}$ \\
\hline \multicolumn{7}{|l|}{ Initial $\mathrm{NO}_{r}$ emissions } \\
\hline $\begin{array}{l}\left(\mathrm{tNO}_{2} / \text { year }\right) \\
\left(\mathrm{mgNO}_{2} / \mathrm{Nm}^{3}\right) \dagger\end{array}$ & $\begin{array}{c}3968 \cdot 0 \\
850\end{array}$ & $\begin{array}{l}3415 \cdot 2 \\
1100\end{array}$ & $\begin{array}{l}3547 \cdot 2 \\
1120\end{array}$ & $\begin{array}{l}3710 \cdot 6 \\
850\end{array}$ & $\begin{array}{l}9260 \cdot 0 \\
1240\end{array}$ & $\begin{array}{c}1924 \cdot 0 \\
810\end{array}$ \\
\hline
\end{tabular}

TABLE 1. Characteristics of the power plants

$\dagger$ Maximum concentrations adjusted for the legal conditions governing the presence of $\mathrm{O}_{2}$ in flue gas. 
Despite their comparative similarity of design, there are marked differences between them regarding:

1. Net capacity - which lies between $135 \mathrm{MW}(\mathrm{F})$ and $280 \mathrm{MW}(\mathrm{E})$.

2. Fuel-coal from different sources, sometimes with an admixture of gas from coke-oven or blast-furnace sources.

3. Hours of operation-while some of the power plants work around the clock, others only function by day.

4. Capacity factors lie between $\mathbf{4 7 0 0}$ hours per year and close to 7000 hours per year.

5. The amount of space available in the vicinity of the boiler houses constitutes a serious constraint on the installation of pollution reduction equipment.

6. The design of the heating equipment--there are significant technical differences here, particularly with respect to the design and positioning of the burners and the geometry of the combustion chambers.

Such site-specific factors affect both initial pollutant emission and emission reduction costs corresponding to the new legally allowable maximum emission levels.

\subsection{LEGISLATION}

Two legislations-the Belgian and the EEC-must be taken into account. These establish emission standards in the form of maximum values $\left(N_{\mathrm{L}}\right)$ for concentrations of pollutants in flue gas, and thus fix emission levels $\left(E_{T \mathrm{~L}}\right)$ or emission reduction levels $\left(D_{T \mathrm{~L}}\right)$ which must not be exceeded. These regulations are recent and apply to combustion facilities of more than $50 \mathrm{MW}_{\mathrm{th}}$ (Moniteur Belge, 1986, 1987; Official Journal, 1988).

Although similar in certain respects, the Belgian (Table 2) and EEC (Table 3) legislations differ in a number of respects, particularly with regard to maximum pollutant concentrations in flue gas.

As far as maximum sulphur dioxide $\left(\mathrm{SO}_{2}\right)$ values are concerned, the Belgian regulations lay down values of $400 \mathrm{mg} / \mathrm{Nm}^{3}$ for coal- and oil-fired combustion facilities of more than $300 \mathrm{MW}_{\text {th }}$.

TABLE 2. Emission standards in Belgium as laid down by Royal Decree $\left(P \geqslant 50 \mathrm{MW}_{\mathrm{th}}\right)$

\begin{tabular}{lccc}
\hline \multirow{2}{*}{ Fuel type } & \multicolumn{2}{c}{ Maximum emission limits in $\mathrm{mg} / \mathrm{Nm}^{3}$ for new plants $\dagger$} \\
\cline { 3 - 4 } & $\begin{array}{c}\text { Nominal thermal } \\
\text { capacity }\left(\mathrm{MW}_{\mathrm{th}}\right)\end{array}$ & $\mathrm{SO}_{2}$ & $\mathrm{NO}_{x}$ \\
\hline Solid & $50-100$ & 2000 & 800 \\
& $100-300$ & 1200 & 800 \\
& $>300$ & 400 & 650 \\
Liquid & $50-100$ & 1700 & 450 \\
& $100-300$ & 1700 & 450 \\
& $>300$ & 400 & 450 \\
Gas & All plants & 35 (in general) & 350 \\
& & 5 (liquid gas) & 350 \\
& & 100 (coke-oven gas) & 350 \\
\hline
\end{tabular}

$\dagger$ Whose operation licence is issued after 3 June 1987, either new, or existing but subject to conversion. $P=$ nominal thermal capacity in $\mathrm{MW}_{\mathrm{th}}$. 
TABLE 3. Emission Standards as laid down by EEC Commission $\left(P \geqslant 50 \mathrm{MW}_{\mathrm{th}}\right)$

\begin{tabular}{|c|c|c|c|}
\hline \multirow{2}{*}{ Fuel type } & \multirow{2}{*}{$\begin{array}{l}\text { Nominal thermal } \\
\text { capacity }\left(\mathrm{MW}_{\mathrm{th}}\right)\end{array}$} & \multicolumn{2}{|c|}{ Maximum emission limits in $\mathrm{mg} / \mathrm{Nm}^{3}$ for new plants $\dagger$} \\
\hline & & $\mathrm{SO}_{2}$ & $\mathrm{NO}_{x}$ \\
\hline Solid & $\begin{array}{r}<100 \\
100-500 \\
>500\end{array}$ & $\begin{array}{c}2000 \\
-4 \times P\left(\mathrm{MW}_{\mathrm{th}}\right)+24001300 \\
400\end{array}$ & $\begin{array}{c}650 \\
(\text { Volatile content: }<10 \%)\end{array}$ \\
\hline Liquid & $\begin{array}{r}<300 \\
300-500 \\
>500\end{array}$ & $\begin{array}{c}1700 \\
-6 \times P\left(\mathrm{MW}_{\mathrm{th}}\right)+3400 \\
400\end{array}$ & 450 \\
\hline Gas & All plants & $\begin{array}{l}35 \text { (in general) } \\
5 \text { (liquid gas) } \\
800 \text { (gas from coke-oven } \\
\text { refineries and blast } \\
\text { furnaces) }\end{array}$ & 350 \\
\hline
\end{tabular}

† Whose first operating licences are issued from 1 July 1987.

$P=$ nominal thermal capacity in $\mathrm{MW}_{\mathrm{th}}$.

On the other hand, for solid fuel facilities of between 100 and $500 \mathrm{MW}_{\text {th }}$, the EEC regulations advocate maximum values which are much less strict and linearly degressive. The maximum limits applicable to gas-fired facilities are identical in the two legislations except in the case of gas from blast furnaces and coke-oven plants. As far as gas from these latter sources is concerned, the Belgian legislation imposes stricter maximum values $\left(35 \mathrm{mg} / \mathrm{Nm}^{3}\right.$ for blast furnace gas and $100 \mathrm{mg} / \mathrm{Nm}^{3}$ for coke-oven gas) than the EEC regulations $\left(800 \mathrm{mg} / \mathrm{Nm}^{3}\right.$ for both).

The maximum values for the discharge of nitrogen oxides $\left(\mathrm{NO}_{x}\right)$ are identical in the two legislations. However, the EEC legislation defines $\mathrm{NO}_{x}$ ceilings and reduction targets in the form of $\mathrm{NO}_{2}$ but says nothing about maximum limits as such expressed in terms of $\mathrm{NO}$ or $\mathrm{NO}_{2}$.

In view of these regulation differences, we opted for the strictest possible maximum limits with respect to facilities of more than $300 \mathrm{MW}_{\text {th }}$ as in the reference sample, i.e.:

- $400 \mathrm{mg} \mathrm{SO} / \mathrm{Nm}^{3}$ and $650 \mathrm{mg} \mathrm{NO} / \mathrm{Nm}^{3}$ for flue gas from the burning of coal;

- $35 \mathrm{mg} \mathrm{SO} / \mathrm{Nm}^{3}$ and $350 \mathrm{mg} \mathrm{NO} / \mathrm{Nm}^{3}$ for flue gas from the burning of blast furnace gas;

- $100 \mathrm{mg} \mathrm{SO}_{2} / \mathrm{Nm}^{3}$ and $350 \mathrm{mg} \mathrm{NO} / \mathrm{Nm}^{3}$ for flue gas from the burning of coke-oven gas.

Since some coal-fired facilities burn an admixture of gas, the maximum values for such facilities are weighted in proportion to the thermal output of each type of fuel as specified in the two sets of regulations.

The maximum emission limits established in this way correspond to the legal emission standards to be complied with by the power plants in the reference sample. The reduction in the level of emission $\left(D_{T L}\right)$ resulting from the application of these standards (cf. Tables 4 and 5) in each individual source determines the overall residual emission targets $\left(E_{T \mathrm{~L}}\right)$ which must not be exceeded by the group of sources when emission trading is achieved.

Before turning to the actual application of the emission trading programme, it would 
be useful to detail some emission limitation scenarios and so to select a series of possible emission reduction technologies to cover the range in which $\mathrm{SO}_{2}$ and $\mathrm{NO}_{x}$ emissions are on the decrease.

The programme contains two distinct scenarios, which differ according to the pollutant involved.

\subsection{SCENARIOS INVOLVING A REDUCTION IN SULPHUR DIOXIDE $\left(\mathrm{SO}_{2}\right)$ EMISSIONS}

The strategies for the reduction of these emissions are based on the application of four control technology options:

\subsubsection{Option zero $(\mathrm{i}=1)$}

No technological measure is taken to control of sulphur dioxide emissions. The concentrations (in $\mathrm{mg} \mathrm{SO}_{2} / \mathrm{Nm}^{3}$ ) of $\mathrm{SO}_{2}$ in the flue gas discharged amount to the values given in Table 1. With this option, emissions reduction costs are nil.

\subsubsection{The use of cleaned coal $(\mathrm{i}=2)$}

The reduction in sulphur content of coal is a comparatively inexpensive method applied today to achieve moderate sulphur abatement. Within the present context, coal can be purchased either desulphurized (up to a $20 \%$ maximum of the total sulphur) or nondesulphurized. This cost is considered to be variable.

\subsubsection{Flue gas desulphurization (FGD wet scrubbing)}

Includes two options $\$$ : the desulphurization of $50 \%$ of the flue gas stream (partial scrubbing) $(i=3)$; and the desulphurization of $100 \%$ of the flue gas stream $(i=4)$.

(a) The desulphurization (FGD) of $50 \%$ of the flue gas (partial scrubbing): as it emerges from the boiler, the flue gas is divided into two streams that pass through two identical ducts. This allows for the desulphurization of $50 \%$ of the flue gas, i.e. that passing through one or another of the two ducts. In the case of this option, which has a maximum removal rate of $47.5 \%$, it is considered that: fixed costs $=$ the cost of capital $\S$ plus labour; variable costs $=$ the cost of the utilities (electricity, water, formic acid and lime, all substracted from the sale of the by-product gypsum); and total annual costs, as the sum of the two-above costs are reported for the first year of power plant operation.

(b) The desulphurization (FGD) of $100 \%$ of the flue gas: a high removal rate $(95 \%)$ can be attained with the desulphurization of all $(100 \%)$ the flue gas stream. The assumptions relating to fixed variable and total annual costs are as above.

\subsection{SCENARIOS INVOLVING A REDUCTION IN NITROGEN OXIDES $\left(\mathrm{NO}_{x}\right)$ EMISSIONS}

The strategies for controlling nitrogen oxides involve five increasingly more severe control technology options.

\footnotetext{
¥ The wet desulphurization of flue gas (FGD) is currently on line and is a reliable method. Capital and operating costs come mainly from technical reports (Schärer and Haug, 1986; CITEPA, 1987; OCDE, 1986), or have been provided by the manufacturers (see also Hecq, 1984).

$\S$ Investment includes foundation, building, supplies, erection, start-up, engineering, licence, insurance, taxes, maintenance and interest during construction. Assuming interest rate $8.6 \%$ and depreciation $5 \%$.
} 


\subsubsection{Option zero $(\mathrm{i}=1)$}

Apart from reburning or tangentially fired, no combustion technical modification is done to reduce nitrogen oxides. The resultant $\mathrm{NO}_{x}$ emissions and concentrations amount to the values are given in Table 1.

\subsubsection{The use of low $N O_{\mathrm{x}}$ burners $(\mathrm{i}=2)$}

The replacement of standard burners by low $\mathrm{NO}_{x}$ models enables a significant reduction to be made in the $\mathrm{NO}_{x}$ content of flue gas emissions. It is considered that the installations of this type of burner in the power plants under study would achieve $30 \% \mathrm{NO}_{x}$ reduction. The cost of this type of equipment is considered to be fixed. Operating costs are negligible.

\subsubsection{Selective catalytic reduction (SCR) - the 'cold end' system}

There are three options: the catalytic treatment with ammonia of $50 \%$ of the flue gas stream $(i=3)$; the combination of this option with the use of low $\mathrm{NO}_{x}$ burners $(i=4)$ and the catalytic denitrification of the whole $(100 \%)$ flue gas stream $(i=5)$.

(a) The selective catalytic reduction (SCR) of $50 \%$ of the flue gas stream: retrofitting an SCR "cold end" unit to one of the existing ducts and the subsequent mixing of flue gas enables the $\mathrm{NO}_{x}$ content (expressed in terms of $\mathrm{NO}_{2}$ ) of the flue gas to be reduced with a maximum efficiency rate of $42.5 \%$. For this option, it is considered that: fixed costs $=$ the cost of capital 7 and the cost of the catalyst and the reheating of the flue gas; these latter costs do not depend on the rate of denitrification; variable costs $=$ the cost of the reagent $\left(\mathrm{NH}_{3}\right)$; and total annual costs, as the sum of the two above costs, are reported for the first year of power plant operation.

(b) The combination of the selective catalytic denitrification (SCR) of $50 \%$ of the flue gas output and the use of low $\mathrm{NO}_{x}$ burners: the combined use of the two methods yields $\mathrm{NO}_{x}$ emissions (expressed in terms of $\mathrm{NO}_{2}$ ) to be brought down to a rate of $60 \%$. The costs assumption are estimated as above, and are added together.

(c) The selective catalytic denitrification (SCR) of $100 \%$ of the flue gas: this deep flue gas treatment enables $\mathrm{NO}_{x}$ emissions (expressed in terms of $\mathrm{NO}_{2}$ ) to be brought down to a rate of $85 \%$. The cost of this method matches the hypotheses put forward in connection with the denitrification of $50 \%$ of the flue gas.

Cost functions (i.e. the relationship between total annualized control cost and the reduction level achieved) are set-up taking these assumptions into consideration and according to the formalism developed in the method.

\subsection{THE COST OF APPLYING LEGAL EMISSION STANDARDS $\left(N_{L}\right)$ ON AN INDIVIDUAL BASIS}

Because the credit obtained from emission trading is measured against the situation in the absence of emission trading (i.e. when power plants must comply with legal standards on an individual basis), we first of all analysed this latter situation by means of the cost functions of emission control projected in the method. 


\subsubsection{The reduction of $\mathrm{SO}_{2}$ emissions in the absence of emission trading}

Compliance with the legal emission standards $\left(N_{\mathrm{L}}\right)$ produces a given level of emission reduction. To attain this level, power plants must equip themselves with FGD units capable of desulphurizing $100 \%$ of their flue gas stream $(i=4)$, but without there being any obligation for them to run the equipment to full use. On the basis of this technological option, Table 4 lists $\mathrm{SO}_{2}$ emissions, reduction levels achieved $\left(d_{n t}=d_{n \mathrm{~L}}\right)$ and the cost $\left(c_{n}=c_{n \mathrm{~L}}\right)$ of applying the legal desulphurization standards $\left(N_{\mathrm{L}}\right)$ for each power station on an individual basis. The cut-back in the amounts discharged (emission reduction level) obtained in this way for all the power plants amounts to 22110.4 tonnes of $\mathrm{SO}_{2}$ per year for an annual cost of $\$ 46.8 \mathrm{~m}$. The value of the reduction in emission brought about (i.e. $D_{T L}=22110.4$ tonnes) is significant because it establishes the overall total emission reduction target to be met within the framework of emissions trading.

\subsubsection{The reduction of $N O_{x}$ emissions in the absence of emission trading}

Compliance with the legal standards means that emission reduction levels $\left(d_{m}=d_{n \mathrm{~L}}\right)$ must be attained which involve the use of the technologies alluded to above. Table 5 gives the $\mathrm{NO}_{x}$ emissions, the emission cut-back obtained and the cost of denitrification accruing to each power plant from the application of the $N_{\mathrm{L}}$ standards on an individual basis. The total annual cost is $\$ 11.5 \mathrm{~m}$ for a total reduction level $\left(D_{T \mathrm{~L}}\right)$ of 11128 tonnes of $\mathrm{NO}_{2}$ per year.

It will be noticed that power plants $A$ and $D$ can make use of the cheapest $(i=2)$ technology - "low $\mathrm{NO}_{x}$ " burners - to comply with the legal standards. By employing this technology, they in fact bring down their level of emission more than is necessary to comply with the standard. As an indication, emission reduction and emission values corresponding exactly to the legal standard are given in brackets in Table 5 inasfar as they have a bearing on this case.

\subsection{COSTS ACCRUING FROM THE APPLICATION OF THE EMISSION TRADING PROGRAMME}

It must be remembered that different programmes are applicable according to the pollutant involved, i.e. $\mathrm{SO}_{2}$ or $\mathrm{NO}_{x}$.

\subsubsection{The reduction of $\mathrm{SO}_{2}$ emissions}

The programme allows for a choice between a number of technological options:

1. No new emissions reduction measures $(i=1)$.

2. The total or partial use of cleaned coal $(i=2)$.

3. The complete or partial desulphurization (FGD) of $50 \%$ of the flue gas $(i=3)$.

4. The complete or partial desulphurization (FGD) of all the flue gas $(i=4)$.

For the same annual 22110 tonnes reduction $\left(D_{T L}\right)$ in emissions as that resulting from a compliance with the legal standards, the use of emission trading at the six power plants under study brings about an optimum solution corresponding to a total annual cost $\left(C_{T \min }\right)$ of $\$ 34.5 \mathrm{~m}$. (see Table 4 ).

\subsubsection{The reduction of $N O_{\mathrm{x}}$ emissions}

A series of control technology options are taken into consideration. 
TABLE 4. The reduction of $\mathrm{SO}_{2}$ emissions-a comparison with and without emission trading (1986-U.S.\$)

\begin{tabular}{|c|c|c|c|c|c|c|}
\hline \multirow[b]{3}{*}{ Power plants } & \multicolumn{6}{|c|}{ Scenarios } \\
\hline & \multicolumn{3}{|c|}{ Without emission trading } & \multicolumn{3}{|c|}{ Emission trading } \\
\hline & $\begin{array}{l}\text { Emission } \\
\text { control } \\
\text { technology† }\end{array}$ & $\begin{array}{l}\text { Emission } \\
\text { reduction } d_{n \mathrm{~L}} \\
\text { and } D_{\pi \mathrm{L}} \\
\text { (t } \mathrm{SO}_{2} / \text { year) }\end{array}$ & $\begin{array}{c}\text { Costs } C_{n \mathrm{~L}} \\
\text { and } C_{\pi} \\
\left(\$ 10^{6} / \text { year }\right)\end{array}$ & $\begin{array}{l}\text { Emission } \\
\text { control } \\
\text { technology } \dagger\end{array}$ & $\begin{array}{c}\text { Emission } \\
\text { reduction } d_{n u} \\
\text { and } D_{\pi \mathrm{L}} \\
\left(\mathrm{t} \mathrm{SO}_{2} / \text { year }\right)\end{array}$ & $\begin{array}{c}\text { Costs } C_{n} \text { and } \\
C_{T \mathrm{~L}} \\
\left(\$ 10^{6} / \text { year }\right)\end{array}$ \\
\hline A & $\begin{array}{c}i=4 \\
\text { (part.) }\end{array}$ & $5525 \cdot 2$ & $9 \cdot 400$ & $i=4$ & $7014 \cdot 1$ & $9 \cdot 776$ \\
\hline B & $\begin{array}{c}i=4 \\
\text { (part.) }\end{array}$ & $3294 \cdot 8$ & $5 \cdot 676$ & $i=4$ & $4198 \cdot 8$ & $5 \cdot 956$ \\
\hline $\mathrm{C}$ & $\begin{array}{c}i=4 \\
\text { (part.) }\end{array}$ & $2319 \cdot 7$ & 6.561 & $\begin{array}{c}i=2 \\
\text { (part.) }\end{array}$ & $534 \cdot 1$ & 1.426 \\
\hline D & $\begin{array}{c}i=4 \\
\text { (part.) }\end{array}$ & $4769 \cdot 1$ & $9 \cdot 279$ & $i=4$ & $6108 \cdot 4$ & $9 \cdot 657$ \\
\hline E & $\begin{array}{c}i=4 \\
\text { (part.) }\end{array}$ & $4554 \cdot 0$ & $10 \cdot 916$ & $i=2$ & $1160 \cdot 3$ & $2 \cdot 322$ \\
\hline F & $\begin{array}{c}i=4 \\
\text { (part.) }\end{array}$ & $1647 \cdot 6$ & 4.975 & $i=4$ & $3022 \cdot 3$ & $5 \cdot 381$ \\
\hline Total & - & $22110 \cdot 4$ & $46 \cdot 807$ & - & $22110 \cdot 0$ & $34 \cdot 518$ \\
\hline $\begin{array}{l}\text { Total (mill./net } \\
\mathrm{kWh} \text { ) }\end{array}$ & - & - & $7 \cdot 16$ & - & - & $5 \cdot 76$ \\
\hline $\begin{array}{l}\text { Credit } \\
\left(\$ 10^{6} / \text { year }\right)\end{array}$ & - & - & 0 & - & - & $12 \cdot 288$ \\
\hline $\begin{array}{l}\text { Credit } \\
\text { (mill./net kWh) }\end{array}$ & - & - & 0 & - & - & 2.05 \\
\hline Credit (\%) & - & - & 0 & - & - & $26 \cdot 2$ \\
\hline
\end{tabular}

$\dagger i=2:$ use of cleaned coal. $i=4:$ FGD applied to $100 \%$ of the fuel gas stream. (part.): technology not working at full capacity.

1. No new emissions reduction technology $(i=1)$.

2. "Low $\mathrm{NO}_{x}$ " burners $(i=2)$.

3. The selective catalytic denitrification (SCR) of $50 \%$ of the flue gas $(i=3)$ with full or partial (part.) use of the equipment.

4. The combination of "low $\mathrm{NO}_{x}$ " burners and the selective catalytic denitrification (SCR) of $50 \%$ of the flue gas $(i=4)$ with full or partial (part.) use of the equipment.

5. The selective catalytic denitrification (SCR) of the whole flue gas $(i=5)$ with full or partial (part.) use of the equipment.

For a reduction $\left(D_{T \mathrm{~L}}\right)$ in emissions corresponding to the legal standards (10 680 tonnes of $\mathrm{NO}_{2}$ per annum), the application of emission trading to the six power plants gives an optimum solution (Table 5 ) with a total annual cost $\left(C_{T_{\min }}\right)$ of $\$ 7.55 \mathrm{~m}$. 
TABLE 5. The reduction of $\mathrm{NO}_{2}$ emissions-a comparison with and without emission trading (1986-U.S.\$)

\begin{tabular}{|c|c|c|c|c|c|c|}
\hline \multirow[b]{3}{*}{ Power plants } & \multicolumn{6}{|c|}{ Scenarios } \\
\hline & \multicolumn{3}{|c|}{ Without emission trading } & \multicolumn{3}{|c|}{ Emission trading } \\
\hline & $\begin{array}{c}\text { Emission } \\
\text { control } \\
\text { technology } \dagger\end{array}$ & $\begin{array}{l}\text { Emission } \\
\text { reduction } d_{n \mathrm{~L}} \\
\text { and } D_{n} \\
\text { (t } \mathrm{NO}_{2} / \text { year) }\end{array}$ & $\begin{array}{c}\text { Costs } C_{n \mathrm{~L}} \\
\text { and } C_{T \mathrm{~L}} \\
\left(\$ 10^{6} / \text { year }\right)\end{array}$ & $\begin{array}{l}\text { Emission } \\
\text { control } \\
\text { technology† }\end{array}$ & $\begin{array}{l}\text { Emission } \\
\text { reduction } d_{m} \\
\text { and } D_{n} \\
\text { (t } \mathrm{NO}_{2} / \text { year) }\end{array}$ & $\begin{array}{c}\text { Costs } C_{n i} \text { and } \\
C_{T \mathrm{~L}} \\
\left(\$ 10^{6} / \text { year }\right)\end{array}$ \\
\hline A & $\begin{array}{c}i=2 \\
\text { (part.) }\end{array}$ & $\begin{array}{l}1190 \cdot 4 \\
(957.9)\end{array}$ & 0.365 & $i=2$ & $1190 \cdot 4$ & 0.365 \\
\hline B & $\begin{array}{c}i=4 \\
\text { (part.) }\end{array}$ & $1641 \cdot 6$ & $2 \cdot 208$ & $i=2$ & $1024 \cdot 7$ & $0 \cdot 226$ \\
\hline $\mathrm{C}$ & $\begin{array}{c}i=3 \\
\text { (part.) }\end{array}$ & 1484.9 & 2.411 & $i=2$ & $1064 \cdot 0$ & $0 \cdot 316$ \\
\hline $\mathrm{D}$ & $i=2$ & $\begin{array}{l}1113.0 \\
(897 \cdot 6) \ddagger\end{array}$ & 0.365 & $i=2$ & $1113 \cdot 0$ & 0.365 \\
\hline $\mathrm{E}$ & $\begin{array}{c}i=4 \\
\text { (part.) }\end{array}$ & $5097 \cdot 1$ & $4 \cdot 568$ & $i=4$ & $5470 \cdot 4$ & 4.622 \\
\hline $\mathrm{F}$ & $\begin{array}{c}i=3 \\
\text { (part.) }\end{array}$ & $601 \cdot 1$ & 1.632 & $i=3$ & $817 \cdot 7$ & 1.657 \\
\hline Total & - & $\begin{array}{l}11128 \cdot 1 \\
(10680 \cdot 2) \ddagger\end{array}$ & $11 \cdot 544$ & - & $10680 \cdot 2$ & $7 \cdot 551$ \\
\hline $\begin{array}{l}\text { Total (mill./net } \\
\text { kWh) }\end{array}$ & - & - & 1.93 & - & - & $1 \cdot 26$ \\
\hline $\begin{array}{l}\text { Credit } \\
\left(\$ 10^{6} / \text { year }\right)\end{array}$ & - & - & 0 & - & - & 3.998 \\
\hline $\begin{array}{l}\text { Credit } \\
\text { (mill./net kWh) }\end{array}$ & - & - & 0 & - & - & 0.67 \\
\hline Credit (\%) & - & - & 0 & - & - & $34 \cdot 6$ \\
\hline
\end{tabular}

$\dagger i=2$ : Low NO $\mathrm{N}_{\mathrm{x}}$ burners. $i=3$ : catalytic denitrification by SCR of $50 \%$ of the flue gas stream. $i=4$ : the above two methods combined. (part.): Technology not working at full capacity.

$\$$ Accurate value at the legal standard.

\subsection{CREDIT}

As is shown in Tables 4 and 5, emission trading makes it possible to generate large-scale credits. The size of these credits differs according to the pollutant involved.

\subsubsection{The reduction of $\mathrm{SO}_{2}$ emissions}

The overall credit generated by the emission trading programme amounts to $\$ 12 \cdot 288 \mathrm{~m}$. per year, a sum which corresponds to $26 \%$ of the total cost of reducing emissions in power plants that do not make use of emission trading. Expressed in terms of $\mathrm{kWh}$, the credit amounts to 2.05 mill.

Table 4 summarizes all the technological options available to power stations for the reduction of $\mathrm{SO}_{2}$ emissions depending on whether or not they make use of emission trading. These options boil down to: the partial (part.) or complete use of cleaned coal 
$(i=2)$; or the partial (part.) or complete desulphurization (FGD) of the total flue gas $(i=4)$.

The comparison made in Table 4 shows that:

1. With the application of the legal standards on an individual basis (i.e. without emission trading), each of the power plants only makes part-use of the equipment installed for the desulphurization of its total flue gas stream.

2. On the other hand, when emission trading is employed, power plants $C$ and $E$ can make do with desulphurized or semi-desulphurized coal for the same total reduction in emission. As a set-off, the remaining four power plants $(A, B, D$ and F) use to an advanced level the equipment (mentioned in the non-emission trading scenario) for the desulphurization of their whole-fuel gas.

In all the power plants, the failure to employ emission trading is expressed in terms of high costs ranging between $\$ 4.97 \mathrm{~m}$./year and $\$ 10.91 \mathrm{~m}$./year, according to the facility. This variation is explained by the features specific to each of the stations (capacity factor, nominal capacity, fuel characteristics, mode of operation and the difficulty of installing emissions control equipment).

With the application of emission trading, power plants $\mathrm{C}$ and $\mathrm{E}$ use cleaned coal-a cheap but not particularly effective option. Annual emission reduction costs have fallen from $\$ 6.5 \mathrm{~m}$. to $\$ 1.42 \mathrm{~m}$. (C), and from $\$ 10.91 \mathrm{~m}$. to $\$ 2.32 \mathrm{~m}$. (E). In exchange, reduced extra costs (less than $\$ 0.5 \mathrm{~m}$. per year) and a consequently lower additional rate of emissions reduction are the outcome for power plants A, B, D and F. These extra costs relate to the use to an advanced level made of the equipment (mentioned in the nonemission trading scenario) for the desulphurization of their flue gas.

\subsubsection{The reduction of $N O_{\mathrm{x}}$ emissions}

The annual credit generated by emission trading amounts to $\$ 3.99 \mathrm{~m}$. or $34.6 \%$ of the total cost of "legal" emissions reduction effected on an individual basis. Expressed in terms of a net $\mathrm{kWh}$ output, the credit amounts to 0.67 mill.

Table 5 lists the technological choices according to whether or not emission trading is used. It seems that the most effective and costly technology, i.e. the selective catalytic denitrification (SCR) of the whole flue gas is not selected in any of the cases.

For the same total level of emission reduction and with the use of emission trading in place in the "legal" reduction scenario:

1. Power plants B and C turn the strategy to the best account with the use of "low $\mathrm{NO}_{x}$ " burners in place of more complex flue gas denitrification (SCR) equipment.

2. Power plants $\mathrm{A}$ and $\mathrm{D}$ retain their "low $\mathrm{NO}_{x}$ " burners regardless of scenario.

3. Power plants $E$ and $F$ also retain their emissions reduction equipment regardless of scenario, but they use it to full capacity when emission trading is employed.

Depending on whether or not emission trading is employed (Table 5):

1. Power plants $B$ and $C$ generate an appreciated credit in relation to the application of legal emission standards on an individual basis (i.e. without emission trading); this credit runs to $\$ 1.98 \mathrm{~m}$. per year $(2.208-0.226)$ and $\$ 2.09 \mathrm{~m}$. per year $(2.411$ $0.316)$ respectively.

2. In exchange, plants $E$ and $F$ are called on to make an extra effort to reduce emission (to the tune of $\$ 0.08 \mathrm{~m}$. per year). They must make full use of the equipment only partly used in the absence of emission trading. 
3. There is no evident change across the two scenarios for power plants A and D. The emission reduction costs by these plants therefore remain constant. It must, however, be mentioned that the application of the legal standards (no emission trading) on an individual basis means more emission reduction than is necessary (1190.4 and 1113.0 tonnes of $\mathrm{NO}_{2}$ per year), whereas strict compliance with the legal standards results in reductions in emission of 957.9 and 897.6 tonnes of $\mathrm{NO}_{2}$ per year. Good use is made of this bonus in the emission trading strategy.

\subsection{CREDITS FROM EMISSION TRADING AND EMISSION REDUCTION TARGETS}

In order to arrive, in terms of the various degrees of emissions reduction possible, at an evaluation of the amount and extent of the credit generated by emission trading we calculated the cost of the various emission reduction scenarios while varying the total emission targets for $\mathrm{SO}_{2}$ and $\mathrm{NO}_{x}$.

Figures 1 and 2 show that the best credits generated by the emission trading strategy lie in the areas where the emission reduction targets put forward are of an intermediate nature. This phenomenon is particularly noticeable in the case of $\mathrm{SO}_{2}$ emissions (Figure 1). It can easily be explained by the fact that there is a wide choice of technology options in the intermediate area, and this factor makes solutions possible with a satisfactory cost-efficiency ratio. On the other hand, the choices of technology are very limited at the two extremes, where emission standards are either very lax or very strict. Indeed, these choices differ minimally, if at all, depending on whether or not emission trading is employed. The result of this is a low level of credit, if any at all. This same point also applies to $\mathrm{NO}_{x}$ emissions. Nevertheless, the development of the credit generated by emissions trading follows a hump-like curve. This peculiarity derives from the shape of the cost functions.

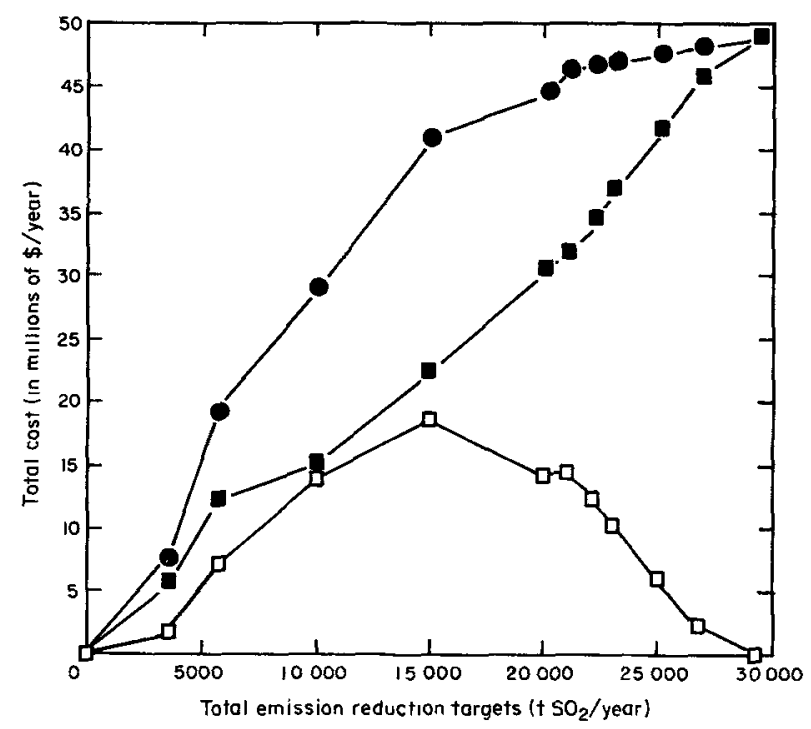

Figure 1. Emission reduction costs and credits as a function of the different targets for the total reduction of $\mathrm{SO}_{2}$ emissions by the six power plants. $-\mathbf{-}_{-}^{-}$, individually applied standards; $-\mathbf{-}-$, emission trading; $-\square-$, credit. 




Figure 2. Emission reduction costs and credits as a function of the different targets for the total reduction of $\mathrm{NO}_{x}$ emissions by the six power plants. - - individually applied standards; - - -, emission trading; $-\square-$ credit.

\section{Conclusions}

Emission trading strategy particularly fits into the electricity sector which is based on long-term and largely centralized planning. In such cases, results confirm the superiority of individually tailored emission reduction programmes as opposed to the application of uniform standards of the type laid down in current regulations. For the same quota of residual emissions, emission trading allows more room for manoeuvre in the choice of emission reduction technology. This means that an optimal techno-economic choice can be operated and that good use can be made of bonus quantities deriving from a lack of congruence between the uniform legal standards and the technologies available.

Thus, it is not surprising that, forced to take draconian measures to reduce the emission of acid pollutants produced by large power plants, foreign authorities have opted for this type of strategy involving selective reductions.

In view of this point, and the very encouraging results of our study, it would be useful to study an emission trading programme such as this but based on a larger number of power plants, particularly since the regulations are now officially known and a decision has been taken as to the composition of Belgium's future network of traditional power plants. These two points had not been finalized when the present study was undertaken.

Finally, following the example of what has been done in other countries such as Denmark, Japan and the U.S.A., it would also be interesting to consider setting up a legal framework which would allow the large-scale adoption of this kind of strategy with its high degree of economic efficiency and its compliance with one ecological goal.

\section{References}

Borowsky, A. R. and Ellis, H. M. (1987). Summary of the final federal emissions trading policy statement. Journal of the Air Pollution Control Association 37, 798-800.

CITEPA (1987). Désulfuration-Dénitrification. Sémınaire de Graz, 12-16 mai 1986. In Etudes documentaires, No.83, CI4399, pp. 1-34. Paris: Centre Interprofessionnel Technique d'Etudes de la Pollution Atmosphérique. 
Hecq W. (1984). An economic and ecological assessment of three electrical power plants: coal, pitch and nuclear power. The integration of damage cost in $\mathrm{kWh}$ cost price and comparisons. In 77 th Anmual Meeting of the Air Pollution Control Association, pp. 1-13. San Francisco, 24-29 June 1984. Doc. 84-81.9.

Hecq, W. and Kestemont, B. (1988). Emission trading et contrôle des rejets de polluants atmosphériques issus des centrales thermiques. Décembre, pp. 1-135. Université Libre de Bruxelles.

Livengood, C. D. and Doctor, R. D. (1986). Coal cleaning: progress and potential. Environmental Progress 4, 1256-263.

Merlet, H. (1986). Technische Lösungen und Betrebserfahrungen, pp. 1-47. Saarberg, Hölter, Lurgi GmbH.

Moniteur Belge (1986). 18 août 1986. Arrêté Royal relatif à la prévention de la pollution atmosphérique engendrée par les nouvelles grandes installations de combustion. Moniteur Belge N232, 16399-16404.

Moniteur Belge (1987). 17 novembre 1987. Arrêté Royal modifiant l'Arrêté Royal du 18 août 1986 relatif à la prévention de la pollution atmosphérique. Moniteur Belge N244, 18996-18997.

OCDE (1986). Compréhension des estimations des coûts de la lutte contre la pollution. In Monographies sur l'Environnement No. 1 (OECD. ed.), pp. 1-55.

Official Journal (1988). Council Directive of 24 November 1988 on the limitation of emissions of certain pollutants into the air from large combustion plants. Official Journal of the European Communities L 336/1, 1 13.

Raufer, R. K., Feldman, S. L. and Jaksch, J. A. (1986). Emissions trading and acid deposition control: the need for ERC leasing. Journal of the Air Pollution Control Association 36, 574-580.

Rentz, O. (1986). Principe de la bulle en R.F.A. et aux U.S.A. In Journée d'Etudes du 4 novembre. Connaissance des Emissions de polluants Atmosphériques, pp. 1-9. Paris: Centre Interprofessionnel Technique d'Etudes de la Pollution Atmosphérique.

Schärer, B. and Haug, N. (1986). The cost of flue gas desulphurization and denitrification in the Federal Republic of Germany. In Fourth Seminar on the Control of Sulphur and Nitrogen Oxides from Stationary Sources (United Nations-Economic Commission for Europe ed.), pp. 1-20. EB AIR/SEM 1/R25. 